\title{
Risk factors for subclinical atherosclerosis in HIV-infected patients under and over 40 years: a case-control study
}

Valéria Maria Gonçalves Albuquerque ${ }^{1,2}$, Josefina Claudia Zírpoli ${ }^{1}$, Demócrito de Barros Miranda-Filho ${ }^{2,3}$, Maria de Fátima Pessoa Militão Albuquerque ${ }^{4}$, Ulisses Ramos Montarroyos ${ }^{1,3}$,

Ricardo Arraes de Alencar Ximenes ${ }^{1,3}$ and Heloísa Ramos Lacerda ${ }^{1,2^{*}}$

\begin{abstract}
Background: Cardiovascular diseases (CVD) are a major cause of death in people with AIDS. Factors contributing to atherosclerosis include traditional risk factors, antiretrovirals and inflammatory factors related to HIV infection. This study set out to compare risk factors associated with subclinical atherosclerosis in individuals under and over 40 years of age.

Methods: Case-control study with 697 HIV/AIDS individuals without HAART or who remain on their first antiretroviral regimen. Of the total, 351 individuals under 40 years and 346 over 40 years were analyzed separately. Subclinical atherosclerosis was assessed by carotid intima-media thickness, using B-mode ultrasound. Multivariate logistic regression was performed to find predictors of subclinical atherosclerosis in the entire group. Subsequent analysis excluded patients with major risk factors for CVD. Magnitudes of associations were expressed by odds ratio (OR) statistical significance, using a 95\% confidence interval and $p$-value $<0.05$.
\end{abstract}

Results: In the <40 years group subclinical atherosclerosis was associated with male gender (OR: 2.77 , 95\% Cl: 1.435.34), nonwhite race (OR: 3.01, 95\% Cl: 1.23-6.53), obesity (OR: 5.13 , 95\% Cl: 1.79-14.7) and metabolic syndrome (OR: $3.30,95 \% \mathrm{Cl}: 1.44-7.58)$. In the group $\geq 40$ years predictors of subclinical atherosclerosis were overweight and obesity (OR $=2.53,95 \% \mathrm{Cl}, 0.85-7.54)$, current CD4 $\geq 350$ cells $/ \mathrm{mL}$ (OR: $2.81,95 \% \mathrm{Cl}: 1.22-6.47)$ and NNRTI use $\geq 5$ years (OR: $2.65,95 \% \mathrm{Cl}: 1.10-6.37)$ or PI use $>5$ years (OR: 1.81, 95\% Cl: 0.38-8.59). In the multivariate model excluding patients with major risk factors for CVD, age, male sex and nonwhite race were associated with subclinical atherosclerosis in the $<40$ y group, while in the $\geq 40$ y group, age, HIV viral load $>10,000$ copies and the use of NNRTI (OR: 7.60, 95\% Cl: 1.61-35.8) or PI $\geq 5$ years (OR: 3.62, 95\% Cl: 0.48-26.8) were associated with subclinical atherosclerosis.

Conclusions: In young people the fight against obesity and metabolic syndrome is the main aim in the prevention of CVD. In individuals aged $\geq 40 \mathrm{y}$, the prevention of obesity is also of great importance. Moreover, the effects of uncontrolled viremia and the prolonged use of HAART appear to be more harmful in the older group.

Keywords: HIV, Risk factors, Atherosclerosis

\footnotetext{
* Correspondence: helramos@terra.com.br

'Department of Tropical Medicine, Universidade Federal de Pernambuco, Recife, Brazil

${ }^{2}$ Department of Clinical Medicine, Universidade de Pernambuco, Recife, Brazil

Full list of author information is available at the end of the article
} 


\section{Background}

Cardiovascular diseases, especially coronary heart disease (CHD), have been the leading cause of mortality in the general population [1] and have now also been identified as a major cause of death in people with AIDS [2].

However, while the association of atherosclerosis and CHD in itself involves a complex inflammatory process, the acquisition of chronic infection with human immunodeficiency virus (HIV) in the same individual adds further complexity to this process. Thus, we have, firstly, atherosclerosis that begins in childhood, characterized by the presence of lymphocytes, foamy macrophages, increased expression of adhesion molecules, proliferation of smooth muscle cells, fat accumulation in the intima layer of the arteries and plaque maturation lipids in the blood vessels [3], and, secondly, endothelial injury caused by HIV [4] itself and by the action of HAART linked to inflammation [5].

Some authors also mention the great frequency with which the well-known risk factors for CHD, namely a family history of premature atherosclerotic disease, smoking, hypertension, obesity and inactivity [6], are found in these patients.

In addition, metabolic disorders like insulin resistance and dyslipidemia induced by antiretroviral agents such as protease inhibitors and nucleoside analogue reverse transcriptase inhibitors are reported to be predictors of cardiac events in these individuals [7]. Although factors potentially contributing to this increased risk include traditional CHD risk factors and antiretroviral medications, more recent data support a role for inflammatory and immunologic factors as central to a complex mechanism [8]. Decreasing CHD risk among HIV-infected patients is likely to involve the modification of inflammatory and immunologic factors through antiretroviral therapy or other novel strategies, as well as the targeted treatment of traditional CHD risk factors [8-10].

In Brazil, the AIDS epidemic affects young people, predominantly those aged from 20 to 39 years, systematically accounting for over $60 \%$ of all reported cases in both sexes [11]. About 250,000 individuals infected with HIV are on combined antiretroviral therapy [12], provided free of charge by the government. However, both the magnitude with which atherosclerosis affects these patients and the impact of the risk factors on the condition remain unknown.

In view of this, the present study, using carotid intima-media thickness (IMT) as a marker of early atherosclerosis in the vascular bed and as a predictor of the development of atherosclerosis [13], was conducted with the following two objectives: firstly, to estimate the frequency with which subclinical atherosclerosis is present in young adults with HIV/AIDS and in those aged 40 years and over; and secondly, to evaluate the association of the traditional risk factors for cardiovascular disease, as well as those related to HIV infection and antiretroviral therapy, with subclinical atherosclerosis in the two groups.

\section{Methods}

Study population, recruitment, and survey methods

A case-control study was carried out in a population of 697 patients, selected from a cohort of patients with HIV/AIDS being screened for cardiovascular diseases in the state of Pernambuco from July 2007 to January 2010, who were treated at Hospital Oswaldo Cruz (University of Pernambuco) and Hospital Correia Picanço (Pernambuco State Department of Health).

The following inclusion criteria were adopted: age 18 years or older, individuals with no antiretroviral therapy or on their first HAART regimen, absence of opportunistic disease in the three months up to the ultrasound examination and no prior angina, heart failure or myocardial infarction.

Cases were defined as individuals over 18 years with subclinical atherosclerosis (IMT greater than $0.8 \mathrm{~mm}$ and/or the presence of atheromatous plaques in the carotid arteries identified by ultrasonography). Controls were those aged over 18 years without subclinical atherosclerosis.

We measured the frequencies of subclinical atherosclerosis and sex, race, schooling, stable partner, traditional risk factors for CHD (smoking, family history of early CHD, arterial hypertension defined according to VIIJC [14], hyperglycemia (fasting glicemia $\geq 100 \mathrm{mg} / \mathrm{dL}$ ), metabolic syndrome, hypercholesterolemia $(\geq 240 \mathrm{mg} /$ $\mathrm{dL})$, low HDL-C $(<40 \mathrm{mg} / \mathrm{dL}$ in men and $<45 \mathrm{mg} / \mathrm{dL}$ in women) and increased LDL-C $(\geq 130 \mathrm{mg} / \mathrm{dL})$, lipodystrophy, hypertriglyceridemia ( $\geq 150 \mathrm{mg} / \mathrm{dL}$ ), alcohol use, drug use, as well as the frequency of factors related to HIV/AIDS/HAART (time elapsed since diagnosis of the infection/HIV disease, history of AIDS, viral load counts at the start of the study, CD4 count $<350$ cels $/ \mathrm{mm}^{3}$ - nadir and at the start of the study, use and duration of use of the antiretroviral regimen).

The study population was divided into two large groups: those under 40 years of age $(<40 \mathrm{y})$ and those aged 40 years and over $(\geq 40 \mathrm{y}$ ), each group being analyzed separately. The reasons for the cut-off point of 40 y were the following: 1) an exploratory analysis of data showed that the chance of atherosclerosis was more than 10 times higher in the 40-49 y age group than in the younger group, and that this chance was even higher in people aged $50 \mathrm{y}$ or over. We thought that, although we could have adjusted our analysis by age, it would be more informative to split the sample into these two groups that might have important differences between them and 2) the $40 \mathrm{y}$ cut-off divided the population of 
the study down the middle (median age of the population was $40 \mathrm{y}$ ).

\section{Traditional and HIV-related risk factors}

To obtain information on risk factors, a questionnaire was applied in individual interviews by trained professionals. We also performed a detailed review of medical records. Measurements of weight, height and waist circumference, as well as blood pressure, were obtained during the interview using the health services' own equipment.

Serum glucose, total cholesterol, high density lipoprotein (HDL), low density lipoprotein (LDL) and triglycerides assays were performed after blood collection following a fasting period of 12 hours. For triglyceride levels below $400 \mathrm{mg} / \mathrm{dL}$, LDL-cholesterol was calculated using the Freidewald formula: $L D L=T C-[H D L+(T G / 5)]$ [15].

The CD4 lymphocyte count was performed by flow cytometry (FACSCalibur - Multitest, San Jose, CA) and the viral load determined by the ultrasensitive test (Amplicor HIV-1 Monitor Assay, Roche Molecular Systems, Branchburg, NJ), whose limits of detection are 50 to 750,000 RNA copies/mL up to six months from the carotid artery ultrasound. The U.S. National Cholesterol Educational Program (NCEP) ATP III [16] definition was used for diagnosis of the metabolic syndrome.

The median time between the USG and the questionnaire was 35 days; between the USG and CD4 and viral load (evaluated simultaneously) it was 96 days; and between the USG and triglycerides /cholestherol (evaluated simultaneously) it was 28 days.

\section{Measurement of IMT and carotid plaque}

The measurements of IMT and determination of atheroma in the extracranial carotid wall were performed using the high-resolution B mode ultrasound equipment GE VIVID Five (Horten, Norway) with a linear transducer $(7.5 \mathrm{MHz})$ and software specifically designed for studying the arteries. The presence of atheroma was defined as a focal prominence greater than $50 \%$ of the vessel wall thickness on the adjacent segments and invading the lumen [17]. Measurements of IMT were obtained on the anterior and posterior walls of the right and left carotid [18] arteries as follows: three measurements on the carotid artery one centimeter proximal to the bifurcation, one measurement in the carotid bulb and two measurements in the first inch of the internal carotid artery. For the final analysis we used the maximum mean of the thickness of each segment. Subclinical atherosclerosis was considered to be present when the thickness of the carotid intima-media was $\geq 0.8 \mathrm{~mm}$ and/or in the presence of an atheroma plaque in any carotid segment. We chose the same cut-off of $0.8 \mathrm{~mm}$ for evaluation of carotid atherosclerosis as that used by Jerico et al. [19].
This choice was based on the fact that the measurement of the common carotid IMT in a normal population of young adults produces values lower than $0.8 \mathrm{~mm}$ [20], with an increase from 0.01 to $0.02 \mathrm{~mm}$ per year. In addition, individuals with a carotid IMT lower than 0.8 $\mathrm{mm}$ have less risk of cardiovascular and cerebrovascular events $(<4.6 \%)$ in six years [21]. Given that the median age of the study population was 40 years, the $0.8 \mathrm{~mm}$ cut-off seemed to be a rational choice.

To minimize bias, the following measures were adopted: a precodified standardized questionnaire and training of all the interviewers in order to standardize techniques; selection of controls from the same population established for cases, provided that both groups satisfied the same inclusion and exclusion criteria; and masking the ultrasound technicians in relation to the traditional risk factors for cardiovascular disease (CVD), status and HIV therapy.

For quality control of the imaging examination 480 repeated measurements of IMT thickness were made, resulting in an inter-class correlation coefficient of 0.866 and a Kappa concordance index of 0.895 .

\section{Data analysis}

Univariate and multivariable logistic regression analysis was performed using the statistical package STATA version 9.0 to identify potential predictors of subclinical atherosclerosis, assessed separately in the two groups $(<40 \mathrm{y}$ and $40 \geq \mathrm{y})$.

The insertion of the data was carried out by double entry, under weekly supervision, thus avoiding transcription errors. Backup copies of the definitive database were made on CD-ROM and subsequently submitted to consistency tests.

Medians were compared using the nonparametric test of Kruskall-Wallis. Comparisons between the groups of categorical variables were performed using the chisquare test and, when necessary, the Fisher Exact test. Logistic regression was used to calculate crude and adjusted odds ratios of the association between the independent variables and the outcome, with the respective 95\% confidence intervals (CI) and p-values (likelihood ratio statistic).

The data analysis was carried out in three steps: 1) univariate analysis of each group to determine the variables closely associated with the outcome: variables associated with the outcome with $\mathrm{P}<0.20$ in the univariate analysis were successively included in a multivariate logistic regression model; 2) final multivariate model: the variables selected in the previous step were inserted into the final multivariate model using the forward selection (including the entire group of patients), and those with a $p$-value $\leq 0.10$ remained in the final model; and 3) a subsequent multivariate logistic regression of factors associated 
with subclinical atherosclerosis was carried out with the exclusion of patients with traditional metabolic risk factors for CVD and smoking, using a forward strategy similar to that used previously.

Several models were tested in the multivariable analysis, and in those which included the metabolic syndrome variable (composite variable) the variables comprising this syndrome were not included in the analysis.

The study was approved by the Ethics and Research Committee of the University of Pernambuco (UPE) and free and informed written consent was obtained from all participants.

\section{Results}

Characteristics of the study participants according to age group

A total of 697 individuals were studied, 351 in the $<40 \mathrm{y}$ group and 346 in the $\geq 40$ y group (Table 1). The mean age was 31.8 years in the former and 47.8 years in the latter. There were no differences between groups regarding sex distribution, proportion of white race, smoking

Table 1 Comparison of qualitative and quantitative variables in HIV-infected individuals according to age group, followed in two referral hospitals in the state of Pernambuco, Brazil

\begin{tabular}{|c|c|c|c|}
\hline Variables & $<40$ years $(n=351)$ & $\geq 40$ years $(n=346)$ & $p$-value \\
\hline \multicolumn{4}{|l|}{ Sociodemographics } \\
\hline Age (years) - Mean (SD) & $31.8(4.96)$ & $47.8(6.14)$ & $<0.001$ \\
\hline Male (\%) & 59.5 & 57.8 & 0.641 \\
\hline White (\%) & 25.6 & 24.9 & 0.811 \\
\hline Stable partner (\%) & 19.4 & 24.3 & 0.117 \\
\hline \multicolumn{4}{|l|}{ Habits } \\
\hline Smoking (\%) & 23.0 & 22.0 & 0.725 \\
\hline Alcohol consumption (\%) & 40.4 & 35.2 & 0.167 \\
\hline Injecting drugs use (\%) & 6.0 & 3.8 & 0.368 \\
\hline \multicolumn{4}{|l|}{ Clinical characteristics } \\
\hline Diabetes (\%) & 0.9 & 6.2 & $<0.001$ \\
\hline Lipodystrophy (\%) & 31.5 & 39.8 & 0.024 \\
\hline Dyslipidemia (\%) & 16.1 & 31.7 & $<0.001$ \\
\hline Metabolic syndrome (\%) & 16.9 & 31.3 & $<0.001$ \\
\hline \multicolumn{4}{|l|}{ HIV-related characteristics } \\
\hline Time elapsed since diagnosis HIV (in months -DP) & $40.5(37.5)$ & $58.4(49.6)$ & $<0.001$ \\
\hline CD4 T-lymphocytes baseline - Median $\left(\mathrm{P}_{25}-\mathrm{P}_{75}\right)$ & $323(158-498)$ & $258(94-473)$ & $0.005^{*}$ \\
\hline Viral load baseline - Median $\left(P_{25}-P_{75}\right)$ & $29600(3341-134000)$ & $57400(6170-205000)$ & $0.026^{*}$ \\
\hline CD4 T-lymphocytes current - Median $\left(P_{25}-P_{75}\right)$ & $391(262-535)$ & $383(242-564)$ & $0.949^{*}$ \\
\hline Viral load, current undetectable $(\%)^{* *}$ & 31.7 & 46.7 & 0.005 \\
\hline HAART duration (in months) Median $\left(\mathrm{P}_{25}-\mathrm{P}_{75}\right)$ & $23.5(9.9-42.6)$ & $36.3(17.7-65.2)$ & $<0.001^{*}$ \\
\hline NNTRI Use (\%) & 36.6 & 47.1 & 0.005 \\
\hline PI use (\%) & 21.7 & 26.9 & 0.112 \\
\hline Without HAART (\%) & 41.3 & 25.7 & $<0.001$ \\
\hline \multicolumn{4}{|l|}{ Laboratory tests } \\
\hline Total cholesterol (mg/dL) - Mean (SD) & $163.5(40.0)$ & $189.6(54.5)$ & $<0.001$ \\
\hline LDL cholesterol (mg/dL) - Mean (SD) & $93.9(38.8)$ & $106.7(40.8)$ & 0.001 \\
\hline HDL cholesterol (mg/dL) - Mean (SD) & $42.2(13.6)$ & $43.5(14.1)$ & 0.216 \\
\hline Triglycerides (mg/dL) - Mean (SD) & $148.8(102.8)$ & $204.6(213.0)$ & $<0.001$ \\
\hline \multicolumn{4}{|l|}{ USG of carotid arteries } \\
\hline Presence of sublinical atherosclerosis (\%) & 23.4 & 66.5 & $<0.001$ \\
\hline Carotid intima thickness (mm) - Median (SD) & $0.742(0.084)$ & $0.841(0.150)$ & $<0.001$ \\
\hline
\end{tabular}

* Kruskal - Wallis test.

** 328 patients with viral load information. 
or drug use. A total of 312 individuals had subclinical atherosclerosis, of whom $82(23.4 \%)$ were in the $<40 \mathrm{y}$ group, whose mean IMT thickness was $0.742 \mathrm{~mm}$, and $230(66.5 \%)$ in the $\geq 40$ y group, whose mean IMT thickness was $0.841 \mathrm{~mm}$, representing a statistically significant difference between the groups $(\mathrm{p}<0.001)$.

Diabetes (6.2\%), lipodystrophy (39.8\%), metabolic syndrome (31.3\%) and dyslipidemia (31.7\%) were more frequent in the $\geq 40 \mathrm{y}$ group. The mean values of total cholesterol (189.6 mg/dL), LDL cholesterol $(106.7 \mathrm{mg} / \mathrm{dL})$ and triglycerides $(204.6 \mathrm{mg} / \mathrm{dL})$ were higher in the $\geq 40 \mathrm{y}$ group, except for mean HDL cholesterol, for which there were no statistical significant differences between the groups $(\mathrm{p}=0.216)$.

A total of $31.7 \%$ of those on HAART in the $<40 \mathrm{y}$ group had an undetectable viral load, and the corresponding figure was $46.7 \%$ in the $\geq 40$ y group ( $\mathrm{p}=$ 0.005), with a median of CD4 391 cells/ $\mu$ in the former group and $383 \mathrm{cells} / \mu \mathrm{l}$ in the latter. The $<40$ y group had been using HAART for less time (median, 23.5 months) than the $\geq 40$ y group (median, 36.3 months) ( $<0.001)$.

Values of carotid IMT in the two different age groups In the group of patients $<40$ years the median of the carotid IMT was higher in patients on HAART than in those without therapy $(\mathrm{p}=0.069)$ and in those with duration of use of HAART $\geq 5$ years $(\mathrm{p}=0.015)$, while no differences were found in patients in different strata of CD4, viral load and types of antiretroviral regimen. In the $\geq 40$ y group carotid IMT was greater in patients with higher CD4 strata $(\mathrm{p}=0.011)$, and in those on HAART for $\geq 5$ years $(0.070)$. There were no differences in the carotid IMT in all viral load strata and different types of antiretroviral regimen (Table 2).

\section{Association between subclinical atherosclerosis and demographic, clinical, laboratory and HIV-related characteristics in the different age groups}

Tables 3 and 4 summarize the results of the univariate analysis in relation to the association of the variables with the presence of subclinical atherosclerosis. In the $<40$ y age group, male gender, nonwhite race, stable partner, hypertension, cholesterol $\geq 240 \mathrm{mg} / \mathrm{dL}$, triglicerydes $\geq 150 \mathrm{mg} / \mathrm{dL}$, fasting glucose $\geq 100 \mathrm{mg} / \mathrm{dL}$, waist circumference, overweight and obesity were significantly associated with subclinical atherosclerosis after adjustment for age. No significant differences were found with other risk factors for CVD such as smoking and HDL or LDL-cholesterol. The $\geq 40$ y group presented a statistically significant difference for age, stable partner, hypertension, overweight, obesity and, and also for altered levels of total cholesterol and LDL cholesterol. As regards the

Table 2 Values of the carotid intima media thickness (IMT) of the patients $<\mathbf{4 0}$ years and $\geq \mathbf{4 0}$ years

\begin{tabular}{|c|c|c|c|c|}
\hline \multirow[t]{2}{*}{ Variables } & \multicolumn{2}{|l|}{$<40$ y group } & \multicolumn{2}{|l|}{$\geq 40$ y group } \\
\hline & Carotid MIT Median $\left(\mathrm{P}_{25} ; \mathrm{P}_{75}\right)$ & $p$-value & Carotid MIT Median $\left(\mathrm{P}_{25} ; \mathrm{P}_{75}\right)$ & $p$-value \\
\hline HAART use & & $p=0.069$ & & $p=0.166$ \\
\hline Yes & $0.735(0.691 ; 0.792)$ & & $0.840(0.772 ; 0.917)$ & \\
\hline No & $0,722(0.677 ; 0.780)$ & & $0.827(0.740 ; 0.915)$ & \\
\hline CD4 T-lymphocytes (cells/mm³) & & $p=0.373$ & & $p=0.011$ \\
\hline$<200$ & $0.720(0.685 ; 0.782)$ & & $0.797(0.742 ; 0.964)$ & \\
\hline 200 to 350 & $0.728(0.681 ; 0.792)$ & & $0.822(0.760 ; 0.919)$ & \\
\hline$\geq 350$ & $0.731(0.693 ; 0.779)$ & & $0.852(0.802 ; 0.920)$ & \\
\hline Viral load (copies/mL) & & $p=0.269$ & & $p=0.616$ \\
\hline$<50$ & $0.745(0.677 ; 0.822)$ & & $0.836(0.765 ; 0.135)$ & \\
\hline 50 to $<10.000$ & $0.742(0.705 ; 0.795)$ & & $0.837(0.757 ; 0.940)$ & \\
\hline 10.000 to $<100.000$ & $0.723(0.681 ; 0.769)$ & & $0.852(0.763 ; 0.922)$ & \\
\hline$\geq 100,000$ & $0.690(0.682 ; 0.741)$ & & $0.831(0.775 ; 0.918)$ & \\
\hline Types HAART regimens & & $p=0.109$ & & $p=0.132$ \\
\hline No HAART use & $0.722(0.677 ; 0.780)$ & & $0.827(0.740 ; 0.915)$ & \\
\hline $\mathrm{Pl}$ & $0.733(0.690 ; 0.767)$ & & $0.782(0.732 ; 0.875)$ & \\
\hline NNRTI & $0.729(0.696 ; 0.784)$ & & $0.837(0.778 ; 0.897)$ & \\
\hline Duration of use of HAART & & $p=0,015$ & & $p=0.070$ \\
\hline No use & $0.722(0.677 ; 0.780)$ & & $0.827(0.740 ; 0.915)$ & \\
\hline$<5$ years & $0.730(0.690 ; 0.790)$ & & $0.830(0.757 ; 0.918)$ & \\
\hline$\geq 5$ years & $0.757(0.730 ; 0.815)$ & & $0.864(0.805 ; 0.915)$ & \\
\hline
\end{tabular}


Table 3 Univariate analysis of the association between subclinical atherosclerosis and socio-demographic variables, habits, and metabolic data in individuals infected with HIV by age group, seen at two referral hospitals in the state of Pernambuco, Brazil

\begin{tabular}{|c|c|c|c|c|c|c|}
\hline \multirow[t]{2}{*}{ Variables } & \multicolumn{3}{|c|}{$<40$ years old $(n=351)$} & \multicolumn{3}{|c|}{$\geq 40$ years old $(n=346)$} \\
\hline & $\begin{array}{l}\% \text { subclinical } \\
\text { atherosclerosis }\end{array}$ & $\mathrm{OR}(\mathrm{Cl})$ & $p$-value & $\begin{array}{l}\% \text { subclinical } \\
\text { atherosclerosis }\end{array}$ & $\mathrm{OR}(\mathrm{Cl})$ & $p$-value \\
\hline Age (continuous) & - & $1.17(1.10-1.25)$ & $<0.001$ & - & $1.11(1.06-1.16)$ & $<0.001$ \\
\hline \multicolumn{7}{|l|}{ Gender } \\
\hline Female & 18.3 & 1.0 & - & 62,7 & 1.0 & - \\
\hline Male & 26.8 & $1.63(0.96-2.75)$ & 0.067 & 69.2 & $1.33(0.84-2.09)$ & 0.213 \\
\hline \multicolumn{7}{|l|}{ Race } \\
\hline White & 13.3 & 1.0 & - & 68.2 & 1.0 & - \\
\hline Nonwhite & 26.8 & $2.38(1.22-4.64)$ & 0.011 & 65.9 & $0.89(0.53-1.52)$ & 0.691 \\
\hline \multicolumn{7}{|c|}{ Schooling (years of study) } \\
\hline 1 to 12 & 22.3 & 1.0 & - & 66.4 & 1.0 & - \\
\hline 13 or more & 32.3 & $1.67(0.77-3.59)$ & 0.190 & 68.3 & $1.10(0.58-2.10)$ & 0.759 \\
\hline \multicolumn{7}{|l|}{ Stable partner } \\
\hline No & 20.1 & 1.0 & - & 62.5 & 1.0 & - \\
\hline Yes & 36.8 & $2.30(1.30-4.08)$ & 0.004 & 78.6 & $2.19(1.23-3.91)$ & 0.008 \\
\hline \multicolumn{7}{|l|}{ Smoking } \\
\hline No & 24.4 & 1.0 & - & 66.4 & 1.0 & - \\
\hline Yes & 19.8 & $0.87(0.36-2.09)$ & 0.759 & 66.7 & $0.97(0.46-1.93)$ & 0.929 \\
\hline \multicolumn{7}{|l|}{ Lipodystrophy } \\
\hline No & 20.6 & 1.0 & - & 63.5 & 1.0 & - \\
\hline Yes & 28.0 & $1.50(0.88-2.54)$ & 0.131 & 70.2 & $1.35(0.84-2.17)$ & 0.206 \\
\hline \multicolumn{7}{|c|}{ Metabolic Syndrome } \\
\hline No & 17.9 & 1.0 & - & 63.9 & 1.0 & - \\
\hline Yes & 49.1 & $4.42(2.44-7.99)$ & 0,000 & 72.0 & $1.44(0.87-2.38)$ & 0.147 \\
\hline \multicolumn{7}{|l|}{ Hypertension } \\
\hline No & 19.1 & 1.0 & - & 61.0 & 1.0 & - \\
\hline Yes & 44.3 & $3.36(1.87-6.03)$ & 0.000 & 76.9 & $2.12(1.28-3.52)$ & 0.004 \\
\hline \multicolumn{7}{|c|}{ Waist circumference $(\mathrm{cm})$} \\
\hline Normal & 19.2 & 1.0 & - & 62.3 & 1.0 & - \\
\hline Abnormal* & 41.2 & $2.94(1.66-5.18)$ & 0.000 & 74.7 & $1.64(0.93-2.89)$ & 0.087 \\
\hline \multicolumn{7}{|l|}{ BMI $\left(\mathrm{kg} / \mathrm{m}^{2}\right)$} \\
\hline$<25$ & 15.5 & 1.0 & - & 60.0 & 1.0 & - \\
\hline$\geq 25$ and $<30$ & 32.6 & $2.63(1.49-4.67)$ & 0.001 & 75.2 & $2.02(1.19-3.42)$ & 0.008 \\
\hline$\geq 30$ & 52.9 & $6.14(2.86-13.2)$ & 0.000 & 81.2 & $2.88(1.13-7.32)$ & 0.025 \\
\hline \multicolumn{7}{|c|}{ Total cholesterol (mg/dL) } \\
\hline$<200$ & 21.7 & 1.0 & - & 62.6 & 1.0 & - \\
\hline $200-<240$ & 28.6 & $1.44(0.69-2.98)$ & 0.323 & 69.4 & $1.35(0.79-2.32)$ & 0.269 \\
\hline$\geq 240$ & 42.1 & $2.62(1.01-6.80)$ & 0.048 & 83.0 & $2.89(1.22-6.84)$ & 0.015 \\
\hline \multicolumn{7}{|c|}{ HDL-cholesterol $(\mathrm{mg} / \mathrm{dL}) * *$} \\
\hline Normal & 24.8 & 1.0 & - & 64.8 & 1.0 & - \\
\hline Low & 22.4 & $0.87(0.52-1.44)$ & 0.596 & 67.7 & $1.13(0.72-1.79)$ & 0.579 \\
\hline
\end{tabular}


Table 3 Univariate analysis of the association between subclinical atherosclerosis and socio-demographic variables, habits, and metabolic data in individuals infected with HIV by age group, seen at two referral hospitals in the state of Pernambuco, Brazil (Continued)

\begin{tabular}{|c|c|c|c|c|c|c|}
\hline \multicolumn{7}{|c|}{ LDL-cholesterol (mg/dL) } \\
\hline$<130$ & 22.2 & 1.0 & - & 61.5 & 1.0 & - \\
\hline$\geq 130$ & 30.4 & $1.53(0.77-3.05)$ & 0.225 & 82.9 & $3.02(1.58-5.82)$ & 0.001 \\
\hline \multicolumn{7}{|c|}{ Triglycerides (mg/dL) } \\
\hline$<150$ & 18.9 & 1.0 & - & 63.9 & 1.0 & - \\
\hline$\geq 150$ & 31.4 & $1.96(1.17-3.28)$ & 0.010 & 69.3 & $1.27(0.80-2.01)$ & 0.296 \\
\hline \multicolumn{7}{|c|}{ Fasting glucose (mg/dL) } \\
\hline$<100$ & 21.6 & 1.0 & - & 65.6 & 1.0 & - \\
\hline$\geq 100$ & 35.7 & $2.01(1.01-4.01)$ & 0.046 & 72.4 & $1.39(0.81-2.38)$ & 0.227 \\
\hline
\end{tabular}

*Men: waist $>102 \mathrm{~cm}$; women: waist $>88 \mathrm{~cm}$.

**Low HDL-cholesterol $<40 \mathrm{mg} / \mathrm{dL}$ in men and $<45 \mathrm{mg} / \mathrm{dL}$ in women.

variables related to HIV, a statistically significant association was observed with CD4 counts > 350 cells $/ \mathrm{mL}$, the use of nonnucleoside reverse-transcriptase inhibitors (NNRTIs) for more than 5 years. However we found no significant differences in the virological status of HIV.

The multivariate model of the associations of demographic factors, traditional risk factors for CVD and HIV infection with the presence of subclinical atherosclerosis in 697 patients is presented in Table 5. The independent predictors of subclinical atherosclerosis in the $<40 \mathrm{y}$ group were age, male sex, nonwhite race, stable partner, obesity and metabolic syndrome, and in the $\geq 40$ y group they were age, male sex, stable partner, obesity, total cholesterol $>240 \mathrm{mg} / \mathrm{dL}, \mathrm{CD} 4$ lymphocyte count $>350$ cells $/ \mu$ l and duration on NNRTI $\geq 5$ years. Obesity and hypertension presented an association with the presence of subclinical atherosclerosis, but nullified each other when introduced into the multivariate model. Thus hypertension was withdrawn from the final model, since obesity is related to the genesis of hypertension.

In order to verify if an HIV-related effect was masked by traditional risk factors for atherosclerosis two new multivariate models were prepared. The first model was prepared excluding the individuals with the major traditional risk factors that were significant in the overall final model, entitled Model A, resulting in the exclusion of 333 patients as follows: patients with metabolic syndrome $(\mathrm{n}=166)$; obese individuals $(\mathrm{n}=20)$; hypertensives $(\mathrm{n}=77)$; patients with total cholesterol $\geq 240 \mathrm{mg} / \mathrm{dL}$ $(\mathrm{n}=24)$ and smokers $(\mathrm{n}=46)$. The results of the multivariate Model A demonstrated that, in the $<40$ y group, age, male sex and nonwhite race were associated with subclinical atherosclerosis. In the $\geq 40 \mathrm{y}$ group, age, viral load $\geq 10,000$ or 100,000 copies $\mathrm{RNA} / \mathrm{mL}$ and time on PI $\geq 5$ years (OR: 3.62$)$ or time on NNRTI $\geq 5$ years (OR: 7.60) remained as factors independently associated with carotid atherosclerosis. The other multivariate model, entitled Model B, comprised all 333 patients with the major traditional risk factors for cardiovascular disease excluded from Model A. In this multivariate final Model B, among patients $\geq 40$ years, those with CD4 levels $\geq 350$ lymphocytes $/ \mathrm{mm}^{3}$ had a 10.8 higher risk (95\% CI: $2.89-40.4 ; \mathrm{p}<0.001$ ) of presenting subclinical atherosclerosis. Viral load was not associated with atherosclerosis in this group. The use of HAART was not related to atherosclerosis, except for the use of NNRTI $<5$ years.

\section{Discussion}

In our study differences in the magnitude and significance of associations between risk factors and subclinical atherosclerosis were observed between the groups, starting with the higher frequency of atherosclerosis $(66.5 \%)$ in the $\geq 40$ y group than in the $<40$ y group (44.8\%). In patients with HIV/AIDS in the $<40$ y group it was the traditional risk factors such as male sex, nonwhite race, obesity, metabolic syndrome and hypercholesterolemia that were associated with subclinical atherosclerosis. In the $\geq 40$ y group, male sex, overweight and obesity were also associated with subclinical atherosclerosis; however, factors related to HIV and HAART (CD4 above 350 cells $/ \mathrm{mL}$ and use of NNRTI for at least 5 years) were also associated with subclinical atherosclerosis in this age group. Age and stable partner were independent predictors of subclinical atherosclerosis in both groups. Analyzing only patients without major modifiable risk factors related to cardiovascular disease, only age, male sex and nonwhite race seemed to be important with regard to the presence of subclinical atherosclerosis in the $<40$ y group, while in the $\geq 40 y$ group, age, viral load and the use of NNRTI $\geq 5$ years were independently associated with the presence of atherosclerosis. In the group of persons with at least one modifiable risk factor for CVD and $\geq 40 \mathrm{y}$, patients with 
Table 4 Univariate analysis of the association between subclinical atherosclerosis and other factors related to HIV, by age group, seen at two referral hospitals in the state of Pernambuco, Brazil

\begin{tabular}{|c|c|c|c|c|c|c|}
\hline \multirow[t]{2}{*}{ Variables } & \multicolumn{3}{|c|}{$<40$ years old $(n=351)$} & \multicolumn{3}{|c|}{$\geq 40$ years old $(n=346)$} \\
\hline & $\begin{array}{l}\% \text { subclinical } \\
\text { atherosclerosis }\end{array}$ & $\mathrm{OR}(\mathrm{Cl})$ & $p$-value & $\begin{array}{l}\% \text { subclinical } \\
\text { atherosclerosis }\end{array}$ & $\mathrm{OR}(\mathrm{Cl})$ & $p$-value \\
\hline \multicolumn{7}{|c|}{ Time elapsed since HIV diagnosis (years) } \\
\hline$<1$ & 19.3 & 1.0 & - & 55.1 & 1.0 & - \\
\hline 1 to $<5$ & 22.3 & $1.19(0.64-2.25)$ & 0.570 & 65.8 & $1.56(0.81-3.01)$ & 0.179 \\
\hline$\geq 5$ & 30.5 & $1.82(0.91-3.66)$ & 0.090 & 70.6 & $1.95(0.99-3.83)$ & 0.051 \\
\hline \multicolumn{7}{|c|}{ Clinical history of AIDS } \\
\hline No & 24.0 & 1.0 & - & 65.7 & 1.0 & - \\
\hline Yes & 24.2 & $1.01(0.58-1.76)$ & 0.975 & 72.7 & $1.38(0.68-2.81)$ & 0.362 \\
\hline \multicolumn{7}{|c|}{ CD4+ T-lymphocytes (cells $/ \mathrm{mm}^{3}$ ) } \\
\hline$<200$ & 22.2 & 1.0 & - & 53.3 & 1,0 & - \\
\hline 200 to $<350$ & 24.4 & $1.12(0.51-2.48)$ & 0.763 & 63.1 & $1.49(0.81-2.74)$ & 0.193 \\
\hline 350 and more & 21.9 & $0.98(0.42-2.30)$ & 0.963 & 84.0 & $4.59(2.19-9.59)$ & 0.000 \\
\hline \multicolumn{7}{|c|}{ Viral load (copies/mL) } \\
\hline$<50$ & 29.4 & 1.0 & - & 67.5 & 1.0 & - \\
\hline 50 to $<10,000$ & 24.6 & $0.78(0.34-1.81)$ & 0.566 & 62.7 & $0.89(0.41-1.91)$ & 0.767 \\
\hline $10,000<100,000$ & 19.4 & $0.58(0.21-1.61)$ & 0.295 & 72.7 & $1.61(0.54-4.73)$ & 0.384 \\
\hline$>100,000$ & 15.4 & $0.44(0.09-2.21)$ & 0.316 & 68.6 & $1.07(0.32-3.55)$ & 0.905 \\
\hline \multicolumn{7}{|l|}{ HAART use } \\
\hline No & 19.9 & 1.0 & - & 59.5 & 1.0 & - \\
\hline Yes & 26.0 & $1.42(0.85-2.36)$ & 0.184 & 68.9 & $1.50(0.91-2.48)$ & 0.109 \\
\hline \multicolumn{7}{|c|}{ Types HAART regimens } \\
\hline No HAART use & 19.9 & 1.0 & - & 59.5 & 1.0 & - \\
\hline PI & 17.1 & $0.83(0.40-1.71)$ & 0.619 & 59.3 & $0.99(0.54-1.79)$ & 0.977 \\
\hline NNRTI & 31.2 & $1.83(1.05-3.19)$ & 0.031 & 74.2 & $1.95(1.12-3.39)$ & 0.017 \\
\hline \multicolumn{7}{|c|}{ HAART duration of use (years) } \\
\hline No HAART use & 19.9 & 1.0 & - & 59.5 & 1.0 & - \\
\hline$<5$ & 24.7 & $1.32(0.78-2.25)$ & 0.299 & 64.2 & $1.21(0.72-2.06)$ & 0.460 \\
\hline$\geq 5$ & 34.6 & $2.13(0.86-5.27)$ & 0.100 & 81.6 & $3.00(1.46-6.16)$ & 0.003 \\
\hline
\end{tabular}

levels $\geq 350$ lymphocytes/mm3 had a 10.8 higher risk of having subclinical atherosclerosis.

Understanding the risk of cardiovascular disease in individuals with HIV is a complex matter. Since the introduction of HAART, cardiovascular events resulting from atheromatous complications have been reported [22,23], but it is not known to what extent this risk is attributable to the therapy and its adverse effects or to genetic factors, traditional risk factors or even to the inflammatory state associated with HIV [24].

The measurement of CMIT thickness has been increasingly used as a surrogate marker of atherosclerosis due to the long time required for the appearance of clinical events. A systematic review and meta-analysis showed the high predictive capacity of the measurement of CMIT to predict future cardiovascular events such as myocardial infarction and stroke in the general population [25]. The CMIT thickness among HIV-positive patients is higher than among HIV-negative ones and HIV infection is an independent risk factor for the presence of carotid thickening [26-28] and its progression [26].

Our study aimed to examine whether the risk factors associated with increased thickening of CMIT in HIVinfected individuals are different between individuals aged below 40 years and those 40 years or more. This question arose as the exploratory analysis of our data showed that the chance of atherosclerosis was more than 10 times higher in the 40-49 y age group than in the younger group, and that this chance was even higher in people aged 50 y or over. We decided that, although we could have adjusted our analysis by age, it would be more informative to split the sample into these two 
Table 5 Multivariate model of the association between subclinical atherosclerosis with sociodemographic variables, habits, family history, clinical parameters, lipid profile, fasting glucose and features related to HIV by age group including all patients (total of 694 patients)

\begin{tabular}{|c|c|c|c|c|}
\hline \multirow[t]{2}{*}{ Variables } & \multicolumn{2}{|l|}{$<40$ years old } & \multicolumn{2}{|l|}{$\geq 40$ years old } \\
\hline & $\mathrm{OR}(\mathrm{IC})$ & $p$-value & $\mathrm{OR}(\mathrm{Cl})$ & $p$-value \\
\hline Age (continuous) & $1.12(1.05-1.20)$ & 0.001 & $1.11(1.05-1.17)$ & $<0.001$ \\
\hline Male sex & $2.77(1.43-5.34)$ & 0.002 & $1.62(0.94-2.81)$ & 0.080 \\
\hline Nonwhite & $3.01(1.23-6.53)$ & 0.007 & $1.37(0.73-2.57)$ & 0.321 \\
\hline BMI overweight & $1.65(0.79-3.44)$ & 0.344 & $1.93(1.04-3.57)$ & 0.036 \\
\hline Obese & $5.13(1.79-14.7)$ & 0.002 & $2.53(0.85-7.54)$ & 0.095 \\
\hline Metabolic Syndrome & $3.30(1.44-7.58)$ & 0.005 & $1.01(0.54-1.88)$ & 0.968 \\
\hline Total cholesterol $<200$ & 1.0 & & 1.0 & \\
\hline 200 to $<240 \mathrm{mg} / \mathrm{dL}$ & $0.83(0.32-2.03)$ & 0.701 & $1.24(0.66-2.32)$ & 0.491 \\
\hline$\geq 240 \mathrm{mg} / \mathrm{dL}$ & $2.28(0.83-9.40)$ & 0.095 & $2.14(0.76-5.98)$ & 0.145 \\
\hline Stable partner & $2.07(1.03-4.19)$ & 0.041 & $2.41(1.24-4.67)$ & 0.009 \\
\hline CD4+ T-lymphocytes $<200$ & 1.0 & & 1.0 & \\
\hline 200 to $<350$ cels $/ \mathrm{mm}^{3}$ & $0.86(0.33-2.24)$ & 0.758 & $1.18(0.59-2.37)$ & 0.631 \\
\hline$\geq 350$ cels $/ \mathrm{mm}^{3}$ & $0.71(0.24-2.09)$ & 0.542 & $2.81(1.22-6.47)$ & 0.015 \\
\hline \multicolumn{5}{|l|}{ HAART duration of use } \\
\hline No HAART use & 1.0 & & 1.0 & \\
\hline $\mathrm{PI}<5$ years & $0.64(0.27-1.54)$ & 0.323 & $0.67(0.32-1.39)$ & 0.287 \\
\hline $\mathrm{PI} \geq 5$ years & $2.15(0.23-20.1)$ & 0.503 & $1.81(0.38-8.59)$ & 0.453 \\
\hline NNRTI $<5$ years & $1.52(0.74-3.08)$ & 0.248 & $1.31(0.66-2.60)$ & 0.426 \\
\hline NNRTI $\geq 5$ years & $1.94(0.62-6.07)$ & 0.254 & $2.65(1.10-6.37)$ & 0.028 \\
\hline
\end{tabular}

groups, bearing in mind that there might be important differences between them. Another point reinforced our decision, namely the fact that the $40 \mathrm{y}$ cut-off divided our population down the middle (the median age of the population was $40 \mathrm{y}$ ).

Our overall results showed that both traditional and new risk factors (albeit not related to HIV) were strongly associated with the onset of carotid thickening, particularly in the younger population. Thus, male sex, nonwhite race, obesity, metabolic syndrome and elevated levels of total cholesterol were associated with the presence of thickening of CMIT in the group $<40 \mathrm{y}$. This result is in agreement with studies that assessed thickening of CMIT in HIV-positive individuals, which also found the traditional risk factors related to CVD to be the main factors associated with increased CMIT [24,26,29].

The metabolic syndrome was detected in $16 \%$ of the younger group and in $31 \%$ of $\geq 40$ y group of our study. In the general population, the metabolic syndrome is associated with a 2.35-fold greater risk of developing CVD [30] and was an independent factor associated with greater CIMT in younger patients in our study. In the population with HIV, the metabolic syndrome is described as a possible complication of the use of HAART, especially in regimens containing a protease inhibitor [31], and might or might not be suggestive of an indirect effect of HAART in atherogenesis. Nonetheless, in an analysis that included 331 antiretroviral treatment-naive patients conducted by Stein et al., the metabolic syndrome was also an important factor in the presence of carotid lesions [32], suggesting that the role of the metabolic syndrome in CMIT thickening is not necessarily related to the use of HAART.

With regard to obesity as a predictor of CVD risk, our study was in agreement with the literature in an at-risk population not infected by HIV, which reported a linear relationship with thickening of the CIMT in young obese individuals [33].

In the final model of the multivariable analysis of all patients in each age group, no factor related to HIV or its treatment was associated with CMIT thickening in the $<40$ y group. On the other hand, the group of individuals 40 years or more, levels of CD4 > 350 lymphocytes/mm3 and the use of NNRTI > 5 years were associated with CMIT thickening.

One hypothesis is that the role of the traditional risk factors is so important that it was not possible to identify factors specifically related to HIV or to HAART as being associated with the disease, particularly in the 
younger group. This question was assessed by excluding all the patients that presented at least one modifiable risk factor unrelated to HIV (obesity, metabolic syndrome, hypertension, cholesterol above $240 \mathrm{mg} / \mathrm{dL}$ and smoking) in order to check whether some factor related to HIV could be masked. In this important analysis (Table 6, Model A) we found that among patients $<40 \mathrm{y}$ the results were similar, with no association between CMIT thickening and HIV-related factors.

However important HIV-related factors in the group of patients $\geq 40$ y became even clearer after the exclusion of patients with modifiable risk factors unrelated to HIV. The first such finding was the association of the higher CIMT with the use of antiretroviral therapy for more than 5 years. This finding was particularly evident when using NNRTI > 5 years (OR: 7.6), but was also suggested when using PI $>5$ years (OR: 3.62$)$ although the low number of patients using PI $>5$ years in this group did not permit any firm conclusion (only 16 observations).

The second important finding was the association of thickening of CMIT with viremia $\geq 10.000$ copies. The levels of association were shown to be higher the higher the category of viral load. HIV viremia is related to inflammation $[8,24]$, a potent trigger for atherosclerosis
$[3,8]$. This finding is in agreement with that obtained by Baker et al., who assessed the factors associated with progression of CMIT thickening in 389 HIV-infected patients after adjustment for traditional risk factors. They found that low baseline viral load ( $<400$ RNA copies $/ \mathrm{mL}$ ) and the maintenance of viral load supression have been associated with lower thickening of CMIT after a period of 2 years [34].

Thus, despite the heavy weight of traditional factors in the presence of carotid thickening, the chronic use of HAART and high levels of viremia are independent factors for its occurrence, particularly in patients aged 40 years or more.

It might be assumed that a vessel in the process of atherosclerosis "inherent in aging" would suffer a greater impact with the prolonged use of HAART than the still "healthy" vessels of the young. It might also be assumed that there is a synergic action of the process of atherosclerosis "inherent in aging", together with other factors related to the therapy that are yet to be clearly identified. However, the association of atherosclerosis specifically with the use of a PI suggested in previous studies was not observed in our population in either group of patients. This result was consistent with CMIT data from 337 patients, in whom no association was found between

Table 6 Multivariate model of factors related to the presence of subclinical atherosclerosis among 361 individuals without the main risk factors for cardiovascular disease (CVD) (excluding a total of 333 patients = 166 patients with metabolic syndrome, 20 obese patients, 77 hypertensive patients, 24 individuals with total cholesterol $\geq 240 \mathrm{mg} / \mathrm{dL}$ and 46 smokers) (Model A) and among 333 patients with risk factors for cardiovascular diseases (Model B)

\begin{tabular}{|c|c|c|c|c|c|c|c|c|}
\hline \multirow[t]{3}{*}{ Variables } & \multicolumn{4}{|c|}{ Multivariate Model A $(n=361)$} & \multicolumn{4}{|c|}{ Multivariate Model B $(n=333)$} \\
\hline & \multicolumn{2}{|c|}{$<40$ years old $(n=218)$} & \multicolumn{2}{|c|}{$\geq 40$ years old $(n=143)$} & \multicolumn{2}{|c|}{$<40$ years old $(n=133)$} & \multicolumn{2}{|c|}{$\geq 40$ years old $(n=200)$} \\
\hline & $\mathrm{OR}(\mathrm{Cl})$ & $p$-value & $\mathrm{OR}(\mathrm{Cl})$ & $p$-value & $\mathrm{OR}(\mathrm{Cl})$ & $p$-value & $\mathrm{OR}(\mathrm{Cl})$ & $p$-value \\
\hline Age (continuous) & $1.09(1.00-1.19)$ & 0.037 & $1.15(1.06-1.25)$ & 0.000 & $1.21(1.08-1.36)$ & 0.001 & $1.12(1.04-1.21)$ & 0.003 \\
\hline Male sex & $3.02(1.20-7.59)$ & 0.018 & $1.03(0.45-2.34)$ & 0.937 & $1.59(0.64-3.95)$ & 0.311 & $2.53(1.16-5.51)$ & 0.019 \\
\hline Nonwhite race & $3.21(0.90-11.4)$ & 0.071 & $1.23(0.42-3.67)$ & 0.702 & $2.59(0.96-6.99)$ & 0.060 & $1.28(0.55-2.99)$ & 0.557 \\
\hline Stable partner & $1.62(0.64-4.08)$ & 0.306 & $3.97(1.46-10.8)$ & 0.007 & $\mathbf{3 . 1 4}(1.13-8.72)$ & 0.028 & $2.04(0.78-5.36)$ & 0.144 \\
\hline CD4+ T-lymphocytes $<200$ & 1.0 & & 1.0 & & 1.0 & & 1.0 & \\
\hline 200 to $<350 \mathrm{cels} / \mathrm{mm}^{3}$ & $1.07(0.35-3.23)$ & 0.902 & $0.97(0.34-2.79)$ & 0.967 & $0.51(0.07-3.38)$ & 0.486 & $2.52(0.85-7.48)$ & 0.094 \\
\hline$\geq 350 \mathrm{cels} / \mathrm{mm}^{3}$ & $0.49(0.12-1.98)$ & 0.321 & $2.41(0.68-8.47)$ & 0.168 & $0.82(0.11-5.79)$ & 0.847 & $10.8(2.89-40.4)$ & 0.000 \\
\hline Undetectable Viral Load & 1.0 & & 1.0 & & 1.0 & & 1.0 & \\
\hline 50 to $<10,000$ & $0.96(0.24-3.78)$ & 0.954 & $2.16(0.50-9.37)$ & 0.300 & $0.48(0.09-2.40)$ & 0.378 & $0.54(0.15-1.98)$ & 0.355 \\
\hline 10,000 to $<100,000$ & $0.47(0.07-2.93)$ & 0.425 & $5.95(1.00-35.3)$ & 0.050 & $0.83(0.11-6.28)$ & 0.863 & $1.46(0.23-9.11)$ & 0.681 \\
\hline$\geq 100,000$ & $0.33(0.02-4.08)$ & 0.394 & $6.84(0.90-51.8)$ & 0.063 & $0.27(0.00-12.77)$ & 0.512 & $0.91(0.10-7.80)$ & 0.933 \\
\hline \multicolumn{9}{|l|}{ HAART duration of use } \\
\hline No HAART use & 1.0 & & 1.0 & & 1.0 & & 1.0 & \\
\hline$I P<5$ years & $0.51(0.15-1.75)$ & 0.290 & $0.47(0.137-1.66)$ & 0.245 & $0.75(0.19-2.87)$ & 0.682 & $1.72(0.60-4.89)$ & 0.307 \\
\hline $\mathbb{P} \geq 5$ years & - & - & $3.62(0.48-26.8)$ & 0.208 & $0.87(0.05-15.65)$ & 0.925 & - & \\
\hline NNRTI $<5$ years & $0.55(0.18-1.62)$ & 0.281 & $1.79(0.57-5.59)$ & 0.316 & $2.84(0.92-8.68)$ & 0.067 & $2.01(0.71-5.71)$ & 0.189 \\
\hline NNRTI $\geq 5$ years & $2.41(0.59-9.82)$ & 0.218 & $7.60(1.61-35.8)$ & 0.010 & $0.24(0.02-2.53)$ & 0.236 & $2.04(0.63-6.58)$ & 0.229 \\
\hline
\end{tabular}


the use of PI and CMIT thickening [35], and with the findings of a meta-analysis that evaluated the association of regimens containing PI and subclinical atherosclerosis and, as in our study, revealed no associations with this group of drugs [36].

However two of the results related to the use of HAART in the group aged $<40$ y deserve attention: a) there was an association between the median of IMT and HAART use (with a borderline p-value) and duration of use of HAART, though the median value of IMT was below the cut-off point adopted in our study; and b) there was no statistically significant association between HIV-related factors and subclinical atherosclerosis, though the lack of association with use of NNRTI $>5$ years may be due to a problem of power, as suggested by the width of the confidence interval. These data suggest that the use and type of HAART may have some impact on the development of atherosclerosis in this age group, an aspect of the present study that does not allow any firm conclusions.

Our study found an association between a high lymphocyte count and a greater chance of presenting subclinical atherosclerosis in the $\geq 40$ y group; however, this effect disappeared after we excluded those patients with metabolic risk factors for CVD. One possible explanation is that patients who were immunologically compensated (particularly when using HAART), i.e. with high levels of CD4 lymphocytes, are more liable to have traditional metabolic complications such as obesity, metabolic syndrome and hypertension and, consequently, a higher risk of presenting subclinical atherosclerosis $[37,38]$. Hsue has shown that the rate of progression of CMIT thickening was predicted by the CD4 nadir count [26]. However, as in our findings, baseline, nadir or present CD4 lymphocytes count were not associated with the progression of CMIT thickness in the study by Baker (2011) [34] or with CMIT thickness in antiretroviral naïve individuals in the study by Stein (2012) [24].

Finally, in the older group, obesity was also a major factor associated with atherosclerosis, as in the younger one, which should alert us to the importance of fighting it in HIV patients of all ages.

All the studies reported in the literature, including our own, have shown that age is an independent factor associated with CMIT thickening $[24,34,35]$. Nonetheless, unlike previous studies, in which the authors adjusted the risk factors for CMIT by age in their final model of multivariable analysis [24,34], the population in our study was split into two groups, an approach that clearly shows the differences in their respective risk factors.

This study has the limitations of not having included controls not infected with HIV and of not having assessed the intensity of immune activation using biomarkers of inflammation. Another limitation related to the nature of the study is that time is an important factor that was not addressed. Those $<40 \mathrm{y}$ probably had less exposure to both traditional and HIV-related risk factors. For example, taking a hypertensive participant from both groups and assuming the hypertension (or HIV for that matter) developed at about the same age, the participant in the $>40$ y group would have had longer exposure to hypertension (or viremia). This is important in that it distinguishes between hypertension (or viremia) as a relevant risk factor in the $<40$ y group as opposed to exposure to hypertension over time as a risk factor. Given the nature of the study, it is unlikely that this effect can be accounted for statistically.

However one major advantage of our study compared to others should be emphasized, namely the inclusion of individuals on a single antiretroviral regimen, that is, with no change in the class of drug throughout the treatment, a feature that ensures the "purity" of the study with regard to the evaluation of the association of drug classes with atherosclerosis. Another advantage was the elaboration of a model excluding patients with major risk factors for atherosclerosis, for this offers an opportunity to specifically examine the immunologic, virologic and therapeutic factors involved in subclinical atherosclerosis.

In conclusion, the findings of our study suggest that the preventive approach should have somewhat different goals in the prevention of CVD in patients with HIV/ AIDS in different age groups. In young people, especially males, the fight against obesity, hypercholesterolemia and metabolic syndrome are the main aims of prevention. In individuals aged 40 years and over, the prevention of obesity and hypercholesterolemia is also of great importance. Moreover, the effects of uncontrolled viremia and the prolonged use of HAART appear to be more harmful in the older group. New therapeutic strategies with no atherogenic effects are urgently needed.

Competing interests

The authors declare that they have no competing interests.

\section{Authors' contributions}

VMGA carried out the carotid ultrasounds, conceived the study and drafted the manuscript. JCZ and DBMF recruited, selected and followed the patients. MFPMA prepared the questionnaire. RAAX participated in the design, coordinated and supervised the statistical analysis. URM performed the statistical analysis. HRL conceived the study, participated in the design, coordinated and drafted the manuscript. All authors read and approved the final manuscript.

\section{Acknowledgements}

The authors received partial support from the Conselho Nacional de Desenvolvimento Científico e Tecnológico - CNPq (scholarship 310911/2009-5 to HRL, scholarship 301779/2009-0 to MFPM and 300917/2006-6 to RAAX).

\section{Source of funding}

This study received financial support from the Brazilian Ministry of Health Program DST/AIDS/UNESCO. 


\section{Author details}

'Department of Tropical Medicine, Universidade Federal de Pernambuco, Recife, Brazil. ${ }^{2}$ Department of Clinical Medicine, Universidade de Pernambuco, Recife, Brazil. ${ }^{3}$ Postgraduate in Medical Science, Universidade de Pernambuco, Recife, Brazil. ${ }^{4}$ NESC Department, Centro de Pesquisas Aggeu Magalhães/FIOCRUZ, Recife, Brazil.

Received: 3 June 2012 Accepted: 14 June 2013

Published: 18 June 2013

\section{References}

1. Rosamond W, Flegal K, Furie K, Go A, Greenlund K, Haase N, Hailpern SM, Ho M, Howard V, Kissela B, Kittner S, Lloyd-Jones D, McDermott M, Meigs J, Moy C,Nichol G, O'Donnell C, Roger V, Sorlie P, Steinberger J, Thom T, Wilson M, Hong Y, American Heart Association Statistics Committee and Stroke Statistics Subcommittee: Heart disease and stroke statistics-2008 update: a report from the american heart association statistics committee and stroke statistics subcommittee. Circulation 2008, 117(4):e25-146.

2. Mathers CD, Loncar D: Projections of global mortality and burden of disease from 2002 to 2030. PLoS medicine 2006, 3(11):e442.

3. McGill HC Jr: The pathogenesis of atherosclerosis. Clinical chemistry 1988, 34(8B):B33-39

4. Torre D: Nitric oxide and endothelial dysfunction in HIV type 1 infection Clinical infectious diseases: an official publication of the Infectious Diseases Society of America 2006, 43(8):1086-1087.

5. De Lorenzo F, Collot-Teixeira S, Boffito M, Feher M, Gazzard B, McGregor LL: Metabolic-inflammatory changes, and accelerated atherosclerosis in HIV patients: rationale for preventative measures. Current medicinal chemistry 2008, 15(28):2991-2999.

6. Mercie $P$, Thiebaut $R$, Lavignolle $V$, Pellegrin $J$, Yvorra-Vives MC, Morlat $P$, Ragnaud JM, Dupon M, Malvy D, Bellet $\mathrm{H}$, et al: Evaluation of cardiovascular risk factors in HIV-1 infected patients using carotid intima-media thickness measurement. Annals of medicine 2002, 34(1):55-63.

7. Ho JE, Hsue PY: Cardiovascular manifestations of HIV infection. Heart (British Cardiac Society) 2009, 95(14):1193-1202.

8. Hsue PY, Deeks SG, Hunt PW: Immunologic basis of cardiovascular disease in HIV-infected adults. The Journal of infectious diseases 2012, 205(Suppl 3):S375-382.

9. Biagio AD, Bono VD, Rosso R, Viscoli C: HIV and accelerated atheroprogression: role of antiretroviral therapy. Current pharmaceutical biotechnology 2012, 13(1):88-96.

10. Triant VA: HIV infection and coronary heart disease: an intersection of epidemics. The Journal of infectious diseases 2012, 205(Suppl 3):S355-361.

11. Ministério da Saúde, Secretaria de Vigilância em Saúde, Brasil, Departamento de DST, Aids e Hepatites Virais: Boletim Epidemiológico AIDS—Ano VIII no 1-julho a dezembro de 20010/janeiro a junho de 2011. Brasilia, Brasil: Ministério da Saúde, 2011. [Portuguese]. Available at: http://www.aids.gov.br/publicacao/2011/boletimepidemiologico-aids-e-dst-2011.

12. Craven TE, Ryu JE, Espeland MA, Kahl FR, McKinney WM, Toole JF, McMahan MR, Thompson CJ, Heiss G, Crouse 3rd JR: Evaluation of the associations between carotid artery atherosclerosis and coronary artery stenosis. A case-control study. Circulation 1990, 82(4):1230-1242.

13. Urbina EM, Srinivasan SR, Tang R, Bond MG, Kieltyka L, Berenson GS: Impact of multiple coronary risk factors on the intima-media thickness of different segments of carotid artery in healthy young adults (the bogalusa heart study). The American journal of cardiology 2002, 90(9):953-958.

14. Chobanian AV, Bakris GL, Black HR, Cushman WC, Green LA, Izzo JL Jr, Jones DW Materson BJ, Oparil S, Wright JT Jr, et al: Seventh report of the joint national committee on prevention, detection, evaluation, and treatment of high blood pressure. Hypertension 2003, 42(6):1206-1252.

15. Friedewald WT, Levy RI, Fredrickson DS: Estimation of the concentration of low-density lipoprotein cholesterol in plasma, without use of the preparative ultracentrifuge. Clinical chemistry 1972, 18(6):499-502.

16. Executive summary of the third report of the national cholestero education program (NCEP) expert panel on detection, evaluation, and treatment of high blood cholesterol in adults (adult treatment panel III). JAMA 2001, 285(19):2486-2497.
17. Schmidt C, Fagerberg B, Wikstrand J, Hulthe J: Multiple risk factor intervention reduces cardiovascular risk in hypertensive patients with echolucent plaques in the carotid artery. Journal of internal medicine 2003, 253(4):430-438.

18. O'Leary DH, Polak JF, Wolfson SK Jr, Bond MG, Bommer W, Sheth S, Psaty BM, Sharrett AR, Manolio TA: Use of sonography to evaluate carotid atherosclerosis in the elderly. The cardiovascular health study. CHS collaborative research group. Stroke; a journal of cerebral circulation 1991, 22(9):1155-1163.

19. Jerico C, Knobel H, Calvo N, Sorli ML, Guelar A, Gimeno-Bayon JL, Saballs P, Lopez-Colomes JL, Pedro-Botet J: Subclinical carotid atherosclerosis in HIV-infected patients: role of combination antiretroviral therapy. Stroke; a journal of cerebral circulation 2006, 37(3):812-817.

20. Touboul PJ, Grobbee DE, Den Ruijter H: Assessment of subclinical atherosclerosis by carotid intima media thickness: technical issues. European journal of preventive cardiology 2012, 19 (2 Suppl):18-24.

21. Aminbakhsh A, Mancini GB: Carotid intima-media thickness measurements: what defines an abnormality? a systematic review. Clinical and investigative medicine Medecine clinique et experimentale 1999, 22(4):149-157

22. Friis-Moller $N$, Weber $R$, Reiss $P$, Thiebaut $R$, Kirk O, D'Arminio Monforte A Pradier C, Morfeldt L, Mateu S, Law M, et al: Cardiovascular disease risk factors in HIV patients--association with antiretroviral therapy. Results from the DAD study. AIDS (London, England) 2003, 17(8):1179-1193.

23. Aberg JA: Cardiovascular complications in HIV management: past, present, and future. Journal of acquired immune deficiency syndromes (1999) 2009, 50(1):54-64.

24. Stein JH, Hsue PY: Inflammation, immune activation, and CVD risk in individuals with HIV infection. JAMA : the journal of the American Medical Association 2012, 308(4):405-406.

25. Lorenz MW, Markus HS, Bots ML, Rosvall M, Sitzer M: Prediction of clinical cardiovascular events with carotid intima-media thickness: a systematic review and meta-analysis. Circulation 2007, 115(4):459-467.

26. Hsue PY, Lo JC, Franklin A, Bolger AF, Martin JN, Deeks SG, Waters DD: Progression of atherosclerosis as assessed by carotid intima-media thickness in patients with HIV infection. Circulation 2004, 109(13):1603-1608.

27. Lorenz MW, Stephan C, Harmjanz A, Staszewski S, Buehler A, Bickel M, Von Kegler S, Ruhkamp D, Steinmetz H, Sitzer M: Both long-term HIV infection and highly active antiretroviral therapy are independent risk factors for early carotid atherosclerosis. Atherosclerosis 2008, 196(2):720-726.

28. Grunfeld C, Delaney JA, Wanke C, Currier JS, Scherzer R, Biggs ML, Tien PC, Shlipak MG, Sidney S, Polak JF, et al: Preclinical atherosclerosis due to HIV infection: carotid intima-medial thickness measurements from the FRAM study. AIDS (London, England) 2009, 23(14):1841-1849.

29. Mangili A, Polak JF, Skinner SC, Gerrior J, Sheehan H, Harrington A, Wanke CA: HIV infection and progression of carotid and coronary atherosclerosis: the CARE study. Journal of acquired immune deficiency syndromes (1999) 2011, 58(2):148-153.

30. Mottillo S, Filion KB, Genest J, Joseph L, Pilote L, Poirier P, Rinfret S, Schiffrin EL, Eisenberg MJ: The metabolic syndrome and cardiovascular risk a systematic review and meta-analysis. Journal of the American College of Cardiology 2010, 56(14):1113-1132

31. Jerico C, Knobel H, Montero M, Ordonez-Llanos J, Guelar A, Gimeno JL, Saballs P, Lopez-Colomes JL, Pedro-Botet J: Metabolic syndrome among HIV-infected patients: prevalence, characteristics, and related factors. Diabetes care 2005, 28(1):132-137

32. Stein $\mathrm{JH}$, Brown $\mathrm{T}$, Ribaudo HJ, Chen Y, Yan M, Lauer-Brodell E, McComsey GA, Dube MP, Murphy RL, Hodis HN, et al: Ultrasonographic measures of cardiovascular disease risk in antiretroviral treatment-naive individuals with HIV infection. AIDS (London, England) 2013, 27(6):929-937.

33. Freedman DS, Dietz WH, Tang R, Mensah GA, Bond MG, Urbina EM, Srinivasan S, Berenson GS: The relation of obesity throughout life to carotid intima-media thickness in adulthood: the bogalusa heart study. International journal of obesity and related metabolic disorders: journal of the International Association for the Study of Obesity 2004, 28(1):159-166.

34. Baker JV, Henry WK, Patel P, Bush TJ, Conley $\sqcup$, Mack WJ, Overton ET, Budoff M, Hammer J, Carpenter CC, et al: Progression of carotid intima-media thickness in a contemporary human immunodeficiency virus cohort. Clinical infectious diseases : an official publication of the Infectious Diseases Society of America 2011 53(8):826-835. 
35. Mangili A, Gerrior J, Tang AM, O'Leary DH, Polak JK, Schaefer EJ, Gorbach SL, Wanke CA: Risk of cardiovascular disease in a cohort of HIV-infected adults: a study using carotid intima-media thickness and coronary artery calcium score. Clinical Infectious Diseases 2006, 43(11):1482-1489.

36. Hulten E, Mitchell J, Scally J, Gibbs B, Villines TC: HIV positivity, protease inhibitor exposure and subclinical atherosclerosis: a systematic review and meta-analysis of observational studies. Heart (British Cardiac Society) 2009, 95(22):1826-1835.

37. Duprez DA, Neuhaus J, Kuller LH, Tracy R, Belloso W, De Wit S, Drummond F, Lane HC, Ledergerber B, Lundgren J, et al: Inflammation, coagulation and cardiovascular disease in HIV-infected individuals. PloS one 2012, 7(9):e44454.

38. Mariz Cde A, Albuquerque Mde F, Ximenes RA, Melo HR, Bandeira F, Oliveira TG, Carvalho EH, Silva AP, Miranda Filho Dde B: Body mass index in individuals with HIV infection and factors associated with thinness and overweight/ obesity. Cadernos de saude publica 2011, 27(10):1997-2008.

doi:10.1186/1471-2334-13-274

Cite this article as: Albuquerque et al: Risk factors for subclinical atherosclerosis in HIV-infected patients under and over 40 years: a case-control study. BMC Infectious Diseases 2013 13:274.

\section{Submit your next manuscript to BioMed Central and take full advantage of:}

- Convenient online submission

- Thorough peer review

- No space constraints or color figure charges

- Immediate publication on acceptance

- Inclusion in PubMed, CAS, Scopus and Google Scholar

- Research which is freely available for redistribution 